\title{
Understanding the Influence of Wireless Communications and Wi-Fi Access on Customer Loyalty: A Behavioral Model System
}

\author{
Ana Reyes-Menendez, ${ }^{1}$ Pedro R. Palos-Sanchez $\mathbb{D}^{2},{ }^{2}$ \\ Jose Ramon Saura $\left(\mathbb{D},{ }^{1}\right.$ and Felix Martin-Velicia $\mathbb{D}^{3}$ \\ ${ }^{1}$ Department of Business and Economics, Rey Juan Carlos University, Madrid, Spain \\ ${ }^{2}$ Department of Business Organization, Marketing, and Market Research, International University of La Rioja, Logroño, Spain \\ ${ }^{3}$ Department of Business Management and Marketing, University of Sevilla, Sevilla, Spain \\ Correspondence should be addressed to Jose Ramon Saura; joseramon.saura@urjc.es
}

Received 29 May 2018; Accepted 18 October 2018; Published 2 December 2018

Academic Editor: Davide Mattera

Copyright (C) 2018 Ana Reyes-Menendez et al. This is an open access article distributed under the Creative Commons Attribution License, which permits unrestricted use, distribution, and reproduction in any medium, provided the original work is properly cited.

New technologies offer new possibilities to better understand complex consumer behavior points of sale. The data obtained using wireless communications and Wi-Fi services available in restaurants and catering companies make it possible to acquire in-depth knowledge on consumer behavior complexity. In the present study, the PLS-SEM analysis was used to analyze the impact of free wireless communications and Wi-Fi access on customer loyalty. Our results demonstrate that client satisfaction with wireless communications and Wi-Fi access networks services has a direct impact on customer loyalty. Therefore, wireless communications and Wi-Fi networks and technologies available at the points of sale should be updated in order to better meet customers' expectations.

\section{Introduction}

In recent years, advances in technology have spurred a considerable scholarly interest in the research on consumer behavior [1]. Some relevant studies have focused on retail stores, making consumer behavior simultaneously more measurable and more complex. The results of this body of work demonstrate that, due to the use of digital devices, customer experience at points of sale has been considerably enhanced. The digital technology allows for registering the data for further storage, tracking, and use. These data provide the research community with a deeper knowledge of consumer behavior, satisfaction, loyalty, and consumer consumption, as well as enabling the development of new models thereof [2,3].

An important landmark in the retail commerce revolution within stores has been the appearance and democratization of new connectivity options for users $[4,5]$. Along with the mobile channel, tablets with access to social media have also become available at points of sale, bringing about the necessity to integrate these new channels into both online and offline retail commerce [6-8].
Overall, companies should be proactive in their adaptation to the market and provision of positive experiences to their consumers. One way of achieving this goal is providing in-store mobile devices (tablets) that clients can use to search for information about the company's products and even order them (e.g., Apple stores). Alternatively, through in-store wireless communications and Wi-Fi networks, companies can communicate with their clients through mobile devices, as well as track client behavior [9]. These information systems render themselves as complex concepts within companies $[10,11]$.

In many cases, in their search for more information about a company, e.g., showrooming, discounts, or more attractive retail prices $[12,13]$, consumers search for information both inside the store and online, using their mobile devices [8]. Accordingly, the concept of showrooming has recently been complemented by the emergence of the concept of webrooming, which refers to the phenomenon when consumers search for information online and buy offline. Since the emergence of this concept, web-rooming has become a valuable source of information which allows for the development of 
predictive models of complex behavior of Internet users. These models are based on the results of the analysis obtained from mobile devices (see, e.g., [14, 15]).

However, providing a good customer experience, particularly in the hospitality industry, requires more than free wireless communications and Wi-Fi networks services and quality products [16]. For instance, to create a significant experience inside a restaurant, a major aspect that should be taken into account is the presentation of the restaurant environment. Pleasant aroma, nice music, ambient temperature, low noise levels, and adequate lighting, these and many other aspects, should be harmonized with each other to create a space that will favorably influence clients' perception of the restaurant and help them evaluate their experiences in a more positive manner [17-19]. The entirety of these aspects that related to the physical environment of the service transaction and have a meaningful impact on consumer behavior is referred to as servicescape $[20,21]$.

In the present study, we seek to bridge the gap in previous literature on the impact of some elements of the restaurant servicescape on consumer behavior. To this end, we build on previous work on customer loyalty employing several questionnaires handed out at points of sale [22, 23]. This survey-based approach is complemented with a focus on technology. Here, the technological element refers to free wireless communications and Wi-Fi networks access that contributes to a better consumer experience in restaurants $[16,24]$ and enables for collecting relevant data on consumer behavior. These data can further be used to develop predictive models.

The main aim of the present study was twofold. On one hand, through conducting a survey at the moment of consumption, we aimed to assess the importance of factors that have an impact on consumer perceptions of food chain stores. To this end, a questionnaire was sent to those customers who, being within the premises of the restaurant, asked for access to the free wireless communications and Wi-Fi networks offered by the restaurant. We additionally took into account that filling in the survey while using mobile devices could affect the outcome $[30,31]$. Our second goal was to build a predictive model of the complex consumer behaviors within the retail point of sale and of consumer intentions towards restaurants. To achieve this goal, we employed the models proposed by DCunha et al. [25], Zhang and He [27], and Jahanshahi et al. [32]. These models predict the impact of client services on customer satisfaction and actual consumer behavior; the latter becomes tangible through, for example, brand loyalty.

In the present study, we also build on previous research on using wireless communications and Wi-Fi networks for research purposes $[16,24]$ or as part of a restaurant's servicescape $[33,34]$. However, compared to previous research, the novelty of the present study lies in that we use wireless communications and Wi-Fi networks both as an element of our conceptual model and as a means of data collection. In what follows, based on the revision of previously proposed models [35], we propose an updated model and present the results of our exploratory analysis of applying this model to a restaurant's servicescape.

\section{Theoretical Background}

As long as the environment of an establishment can attract clients to shop once, it strives to attract clients to buy repeatedly. According to Sharma and Stafford (2000), customer decision-making process can be influenced more by the environment of retail points of sale than by the product itself. Even though cognitive factors can explain the selection of stores and most purchases planned within the store, the store's atmosphere and the emotional state of the buyers can exert a decisive impact on the complex behavior implied in a purchase. There is a wide scholarly consensus that enhancing the extent to which an environment is enjoyable and boosting the degree to which it highlights innovation are essential factors that determine a company's success [36].

In this context, an important concept to refer to is "atmospherics" - a notion first used to reveal the distinctive capacity of a physical environment to affect client behavior by stimulating customers' perceptive and emotional responses [21]. According to the results of several environmental psychology studies, there is a strong link between emotions and behavior, and, accordingly, complex human behaviors are strongly associated with physical environments [37-39]. These findings are of vital importance in the services sector, such as hotels, restaurants, professional offices, banks, retail stores, and hospitals $[20,21,33,36]$. For that reason, the effect of "atmospherics" in the restaurants sector has been an issue of extensive research and analysis (e.g., [17, 40-43]).

Both pleasure (defined as the degree to which a person feels good, happy, or cheerful) and emotion (i.e., the degree to which a person feels exited, stimulated, alert, or active, which is considered to be one of the main motivations for experience-orientated customers) are important variables related to purchase intention. Emotion interacts with pleasure to facilitate approaching pleasing consumption environments and avoiding unpleasant environments [44].

Consumer loyalty refers to the repeated choice of a catering service by a client, so that the client becomes loyal to the service-providing company, organization, or business [21]. Oliver [45] defined customer loyalty as "an entrenched repurchasing compromise or repeated promotion of a preferred product/service in a consistent way throughout the future, triggering repetitive consumption behaviors of the same brand, regardless of how context or marketing efforts, which hold the potential to cause a change in behavior, may influence them". The development of consumer loyalty is influenced by perceived value, habit, trust, and client satisfaction $[46,47]$.

Major studies that investigated the factors affecting consumer loyalty in catering establishments and other servicesrelated institutions are shown in Table 1. In this body of work, atmospherics and loyalty were key elements to consider [25, 28]. Other essential factors involved in customer loyalty are the quality of products [27], willingness to pay, waiting time (Frank et al., 2008; Sompie \& Pangemanan, 2014), and quality of service [26]. However, new technologies incorporated in the offered services, such as wireless communications and Wi-Fi networks, have rarely been studied. 
TABLE 1: Studies on servicescape and wireless communications and Wi-Fi networks in relation to customer loyalty in restaurants.

\begin{tabular}{ll}
\hline Study & Research aim(s) \\
\hline $\begin{array}{l}\text { DCunha et al. [25] } \\
\begin{array}{l}\text { Frank et al. (2008), } \\
\text { Sompie and }\end{array}\end{array}$ & $\begin{array}{l}\text { To develop a PLS model to measure the influence of environmental elements, design, and social factors on } \\
\text { the perceived quality of servicescape affecting consumer satisfaction and behavior }\end{array}$ \\
$\begin{array}{l}\text { Pangemanan (2014) } \\
\text { the main factors that affect consumers' attitudes }\end{array}$ \\
$\begin{array}{l}\text { [26] } \\
\text { Zhang and He [27] }\end{array}$ \\
$\begin{array}{l}\text { To develop a PLS model that emphasizes a positive relation between quality of services and incentives for } \\
\text { loyalty } \\
\text { That impacts customer satisfaction and consumer loyalty }\end{array}$ \\
Masri et al. [28] & $\begin{array}{l}\text { Using the PLS-SEM methodology, to examine the relationship between the Wi-Fi services' attributes and } \\
\text { tourist satisfaction. All the attributes were found to be significant predictors of tourist satisfaction. }\end{array}$
\end{tabular}

As mentioned in Section 1, the main aim of the present study was to investigate the impact of wireless communications and Wi-Fi networks in the domain of restaurants. Theory-wise, we develop a predictive model of complex consumer behaviors within the retail points of sale and consumer intentions towards restaurants.

The proposed model derives from previous models of the relationship between customer satisfaction and customer loyalty $[25,26,32]$ that have been widely used in various domains. Based on our model, we investigate the role of wireless communications and $\mathrm{Wi}$-Fi networks on satisfaction and customer loyalty in the restaurants sector.

\section{Conceptual Model}

The conceptual model proposed in the present study derives from Zhang and He's [27] model and establishes a link between service quality and willingness to pay, on the one hand, and customer satisfaction, on the other hand; in turn, customer satisfaction exerts a direct impact on customer loyalty. Another contributing factor to customer loyalty is the availability of wireless communications and Wi-Fi networks.

3.1. Willingness to Pay. According to Breidert et al. [48], "typically, the number of possible differentiated products is large and not all candidates can be tested under justifiable budget and time restrictions". The related concept of willingness to pay refers to "the maximum amount an individual is willing to hand over to procure a product or service. The price of the transaction will thus be at a point somewhere between a buyer's willingness-to-pay and a seller's willingness to accept" [29].

3.2. Service Quality. Zeithaml et al. [49] defined service quality as "the extent of discrepancy between the customers' expectations and perceptions". Furthermore, according to Dabholkar, Shepherd, and Thorpe [50], service quality has subdimensions of reliability and responsiveness. Providing a high level of service quality is essential for service providers to be able to compete with other competitors [5153].
3.3. Customer Satisfaction. Customer satisfaction, frequently considered an important factor that affects customer loyalty, refers to "the summary psychological state resulting when the emotion surrounding disconfirmed expectations is coupled with the consumer's prior feelings about the consumption experience" [54].

3.4. Customer Loyalty. Customer loyalty is defined as "a deeply held commitment to rebuy or re-promote a preferred product/service consistently in the future, thereby causing repetitive same-brand or same brand set purchasing, despite situational influences and marketing efforts having the potential to cause switching behavior" [45]. The ultimate goal of these efforts is customer satisfaction [55].

3.5. Wireless Communications and Wi-Fi Networks. Considering that the present study aims to establish the position occupied by the wireless communication and Wi-Fi services in the proposed model (see Figure 1), and assuming they may directly influence customer loyalty $[16,24]$, we incorporated these two variables into the proposed model.

In what follows, all abovementioned constructs are explained in further detail.

3.6. Hypotheses. First studies that focused on service quality emerged in the field of marketing $[56,57]$; afterwards, this construct has been extensively studied in the domain of client service $[58,59]$. Service quality has proved to be of great use in terms of measuring and predicting consumer responses and reactions related to customer satisfaction [6062], the increase of sales [63], or the willingness to pay a premium price [49]. Several studies, including Bitner [20] and Wall and Berry [64], pointed out that that service quality affects consumers experiences. In particular, in their PLSSEM study, Wall and Berry [64] concluded that the physical environment of restaurants has a direct influence on the perception of clients regarding the quality of client service. Furthermore, in their extensive review of 600 case studies, Ulrich et al. [65] demonstrated that design characteristics of the space increase customer attendance, which, in turn, improves the results and quality of the offered client services. 


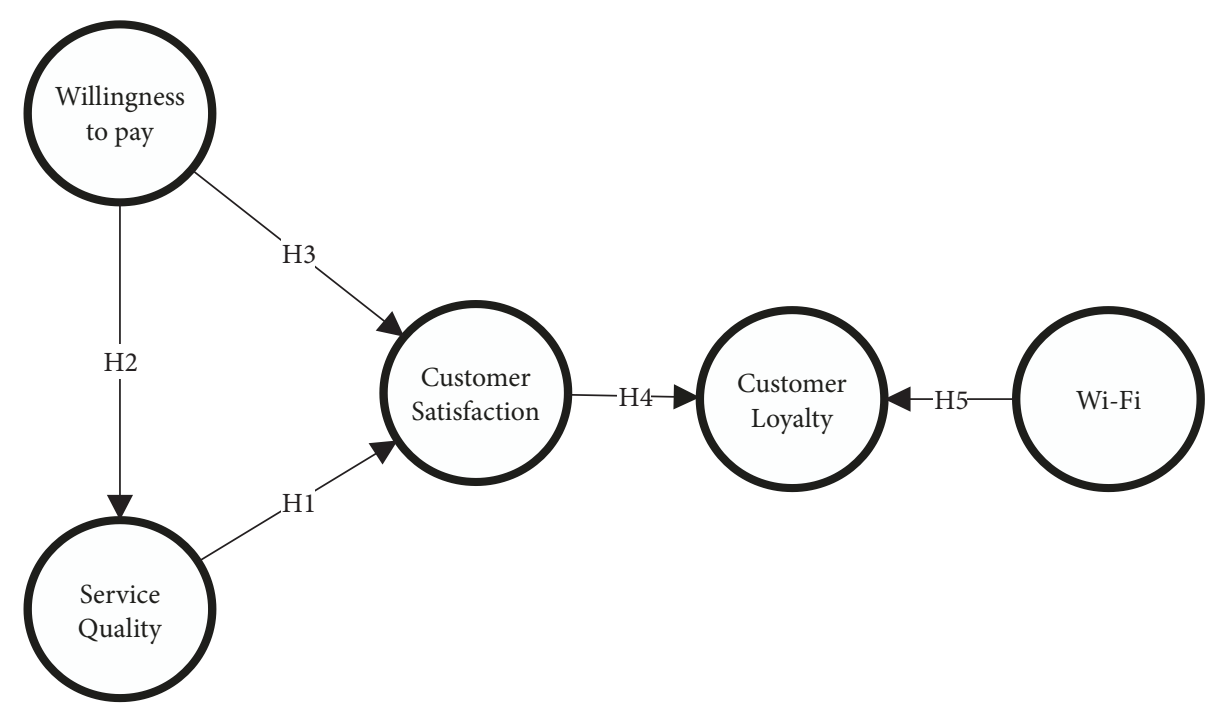

FIGURE 1: Conceptual model proposed in the present study (based on [27]).

In this respect, Afshar Jahanshahi et al. [32] developed a model to demonstrate the existing positive relation between service quality and customer satisfaction constructs.

Based on our review of the literature, the following hypothesis can be formulated:

H1: Service quality positively influences customer satisfaction.

Furthermore, as put forward in the PLS-SEM model by Sompie and Pangemanan (2014) and Frank et al. (2008), willingness to pay is a predictor of consumer behavior. Similarly, Jain and Bala [29] argued that both the price and the intention to pay that price influence the quality of offered services. In the present study, we adopt this view and, consequently, formulate the second hypothesis to be tested.

H2: Willingness to pay positively influences service quality.

Next, several other studies, such as Perutkova [66] and Saravanan and Veerabhadraiah (2003), argued that willingness to pay can positively influence customer satisfaction. Hence, our third hypothesis is as follows:

H3: Willingness to pay positively influences customer satisfaction.

Furthermore, as reported by Kursunluoglu [67], client satisfaction can explain $43.2 \%$ of variance in customer loyalty. Therefore, customer satisfaction can reasonably be expected to have a positive impact on loyalty. Therefore, if sellers wish to improve customer loyalty, customer satisfaction should be enhanced. Accordingly, several researchers argued that there is a direct link between customer satisfaction and customer loyalty $[25,26,32]$. Therefore, the following hypothesis can be formulated: loyalty.

H4: Customer satisfaction positively influences customer

Wireless communications and Wi-Fi networks speed improvements result in an increased service demand [34, 68]. In a study using multiple regression analysis, Jeon [34] identified a relation between wireless communications and
Wi-Fi networks offered by restaurants and the profit earned by those restaurants. Accordingly, the fifth hypothesis to explore in the present study can be formulated as follows:

H5: Quality and free access to wireless communications and Wi-Fi networks positively influence customer loyalty.

Mediation occurs when the relation between the independent variable $(\mathrm{X})$ and the dependent variable $(\mathrm{Y})$ changes when a mediator variable $(\mathrm{M})$ is introduced. The following two mediation hypotheses postulate how or through which means the independent variable (willingness to pay) affects the dependent variable (customer satisfaction) through one or more mediator variables (service quality).

H6: The relation between willingness to pay over customer satisfaction is mediated by service quality.

H7: Wireless communications and Wi-Fi networks have a moderating effect on the relation between customer satisfaction and customer loyalty.

\section{Methodology and Research Data}

To obtain the data, we surveyed clients who went to a restaurant with the capacity for 200 people located in downtown Madrid between March 8, 2017, and January 13, 2018. The restaurant offers Mediterranean food, and the average bill in it amounts to $30 €$. The questionnaires were distributed via the mobile devices of those restaurant clients who connected to the free wireless communications and $\mathrm{Wi}-\mathrm{Fi}$ networks services offered by the restaurant (see Hwang and Jang [69] for the use of this approach; see also Contigiani et al. [70] on the importance of marketing on the use of the data extracted from wireless communications and Wi-Fi networks). In the present study, the obtained data were later uploaded to the cloud. On the other hand, Al-Turjman [71] emphasized the importance of mobile devices for data collection that arises from the fact that these devices are always in the possession of consumers. 
TABLE 2: Sample characteristics.

\begin{tabular}{|c|c|c|c|}
\hline Classifications & Variable & Number & Percentage \\
\hline \multirow[t]{2}{*}{ Gender } & Female & 64 & $54.7 \%$ \\
\hline & Male & 53 & $45.3 \%$ \\
\hline \multirow[t]{6}{*}{ Age } & $18-25$ & 23 & $19.7 \%$ \\
\hline & $26-35$ & 38 & $32.5 \%$ \\
\hline & $36-45$ & 29 & $24.8 \%$ \\
\hline & $46-55$ & 12 & $10.2 \%$ \\
\hline & $56-65$ & 10 & $8.5 \%$ \\
\hline & $>65$ & 5 & $4.3 \%$ \\
\hline \multirow[t]{2}{*}{ Email permission } & No & 2 & $1.7 \%$ \\
\hline & $\mathrm{Si}$ & 115 & $98.3 \%$ \\
\hline \multirow[t]{9}{*}{ Nationality } & Spain & 57 & $48.7 \%$ \\
\hline & Portugal & 5 & $4.3 \%$ \\
\hline & United Kingdom & 27 & $23.1 \%$ \\
\hline & Italy & 8 & $6.8 \%$ \\
\hline & France & 7 & $6.0 \%$ \\
\hline & Romania & 5 & $4.3 \%$ \\
\hline & Nederland & 2 & $1.7 \%$ \\
\hline & Germany & 2 & $1.7 \%$ \\
\hline & Others & 4 & $3.4 \%$ \\
\hline \multirow[t]{5}{*}{ Connections } & $1-10$ & 104 & $88.9 \%$ \\
\hline & $11-20$ & 7 & $6.0 \%$ \\
\hline & $21-30$ & 3 & $2.6 \%$ \\
\hline & $31-50$ & 1 & $0.9 \%$ \\
\hline & $51-100$ & 2 & $1.7 \%$ \\
\hline
\end{tabular}

The length of the questionnaire and the number of items per construct were developed following the guidelines for the questionnaires to be administered in stores using mobile devices $[31,72]$.

The final questionnaire (see the Appendix) included 7 questions related to (1) the price of the products; (2) the quality of the service; (3) the client satisfaction with the amount of attention s/he received; (4) engaging clients; and (5) quality of wireless communications and Wi-Fi networks services. Following Stan and Saporta [73], the participants were asked to rate each of the items on a 10-point scale. Another reason to choose using the 10-point Likert scale was that, as highlighted by Awang et al. [74], a 10-point scale is more efficient than a 5-point one when measuring an equivalently sized sample in structural equations (SEM). Table 2 summarizes the characteristics of the participants.

For data analysis and hypotheses testing, we used structural equation models based on variance (SEM). These models allow one to statistically examine a series of interrelated dependency relations among the variables grounded in the theory and their indicator variables; this is done via measuring the directly observable variables [75]. Among the SEM techniques, the technique of Partial Least Squares regression (PLS) was selected. The modeling of the PLS trajectory can be understood as a complete SEM method which can manage factor models and the models composed for measuring constructs, estimate structural models, and do adjustment trials of the model [76]. The use of PLS is also recommended when there is a low number of observations [77]. In our case, this approach was applicable because the sample was small $(n=117)$. Another reason why we decided to use the PLSSEM method was because the object of study is relatively new, and the theory on the matter has not yet consolidated. Moreover, we also assumed an exploratory perspective [78] in which this data analysis technique is strongly recommended. Finally, we decided to use PLS-SEM because one of the main goals of the present study was to test whether or not our model (see Figure 1) was predictive [78-80]. To determine the minimum size of the sample for the PLS model, Hair et al. [81] recommended using Cohen's tables [82]. We made use of these tables through the software G*Power [83]. In the first place, we checked the dependent construct or the one that had the highest number of predictors, i.e., the one that received the most number of arrows. In our case, such construct was customer satisfaction, which received the value of 2 . To calculate this score, we used the following parameters: the power of the test (power $=1-\beta$ error prob. II) and the size of the effect $\left(f^{2}\right)$. Cohen [84] and Hair et al. [81] recommended the power of 0.80 and the average size of the effect $f^{2}=0.15$. In our case, the value of 2 was taken as the number of predictors obtained, i.e., the number of constructs that establish causality relations with customer satisfaction. Hence, for PLS, the accepted number of participants in the sample for the construct of customer satisfaction was 68 . Therefore, the minimum calculated samples for this example should be 68 cases, which we surpassed using $n=117$. Finally, 


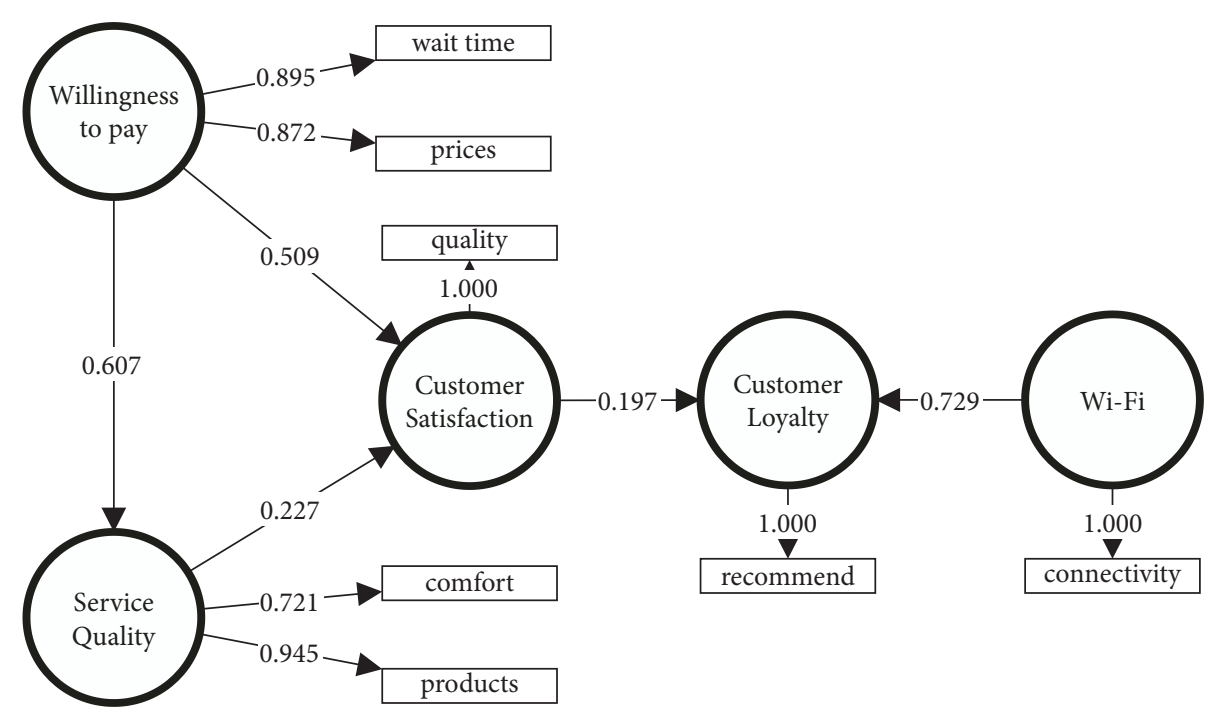

FIGURE 2: Quality of the measurement model and the structural model.

TABLE 3: Measurement items and correlations between the constructs.

\begin{tabular}{lcccccccr}
\hline Constructs & rho_A & Reliability comp. & (AVE) & Customer Sat. & Service Q. & Customer Loy. & Willingness to pay & Wi-Fi \\
\hline Customer Satisfaction & 1.000 & 1.000 & 1.000 & 1.000 & & & & \\
Service Quality & 0.877 & 0.826 & 0.707 & 0.535 & 0.841 & & \\
Customer Loyalty & 1.000 & 1.000 & 1.000 & 0.056 & -0.189 & 1.000 & 0.883 \\
Willingness to pay & 0.724 & 0.877 & 0.780 & 0.646 & 0.607 & 0.039 & -0.110 \\
Wi-Fi & 1.000 & 1.000 & 1.000 & -0.193 & -0.182 & 0.691 & 1.000 \\
\hline
\end{tabular}

the software SmartPLS 3 [85] was used for the PLS-SEM data analysis.

\section{Data Analysis and Results}

The use of PLS unfolds in two steps $[72,86,87]$. The first step requires evaluating the measurement model, which makes it possible to specify the relations between observable variables and theoretical concepts. In the second phase, the structural model is evaluated to see to what extent the causal relations specified by the proposed model are consistent with the available data.

5.1. First Phase: Measurement Model. First, we analyzed the individual reliability of the items, observing the changes of $(\lambda)$. Following Carmines and Zeller [88], the minimum level was established for its acceptance as part of the construct $\lambda>=0.707$. The commonality manifested by variable_ $\left(\lambda^{2}\right)$ is that of the variance which is explained by the factor or construct [89]. Thus, value $\lambda>=0.707$ indicates that each measurement represents at least $50.5 \%$ of the variance of the subjacent construct [90]. The indicators that did not reach the minimum were refined [91]. The results of the measurement model are shown in Figure 2.

Second, we analyzed internal consistency. The measurement of reliability of the construct and convergent validity represents internal consistency measures. The reliability of the construct enables checking if the indicators actually measure the constructs. The results in Table 3 indicate that all constructs are reliable, since their composite/joint_reliability is $>0.7$. These values are considered "satisfactory to good", because they are between 0.70 and 0.95 [92]. On top of that, the most recent developments indicate that the rho. A coefficient is the only consistent reliability measurement [93]. In our case, the variables also comply with the construct reliability requirements, because their rho_A coefficients were over 0.7 level. The most common measure to evaluate the convergent validity in PLS-EM is the AVE. Using the same base as the one used with the individual indicators, a value or AVE of $50 \%$ or superior means that, on average, the construction explains more than a half of the variance of its own indicator $[81,94]$.

As shown in Figure 2, all indicators meet these criteria, because the diagonal elements should be significantly greater than those that are multiform in the corresponding rows and columns. This condition is satisfied for each construct in relation to the remaining constructs (see column 5 in Table 3).

We also used a recently proposed criterion to evaluate the discriminatory validity, the Heterotrait-Monotrait Ratio of Correlations (HTMT), which is an estimation of the correlation of the factor (specifically, a superior limit). To clearly discriminate between two factors, the HTMT should be significantly lower than 1 [76].

Table 4 shows that all variables also reached discriminatory validity following the HTMT criteria. Consequently, 
TABLE 4: Ratio HTMT.

\begin{tabular}{|c|c|c|c|c|c|}
\hline HTMT & Customer Satisfaction & Service Quality & Customer Loyalty & Willingness to pay & $\mathrm{Wi}-\mathrm{Fi}$ \\
\hline \multicolumn{6}{|c|}{ Customer Satisfaction } \\
\hline Service Quality & 0.601 & & & & \\
\hline Customer Loyalty & 0.056 & 0.268 & & & \\
\hline Willingness to pay & 0.757 & 0.833 & 0.046 & & \\
\hline Wi-Fi & 0.193 & 0.221 & 0.691 & 0.129 & \\
\hline
\end{tabular}

TABLE 5: Hypotheses testing.

\begin{tabular}{|c|c|c|c|c|c|c|c|}
\hline No. & Hypothesis & Path coeff $(\beta)$ & Statistics t $(\beta /$ STDEV) & $\mathrm{P}$-value & $\begin{array}{c}\text { Confidence } \\
2.5 \%\end{array}$ & Intervals $97.5 \%$ & Support \\
\hline 1 & Service quality $\longrightarrow$ Customer satisfaction & 0.227 & 2.339 & 0.019 & 0.036 & 0.41 & Yes $^{* *}$ \\
\hline 2 & Willingness to pay $\longrightarrow$ Service quality & 0.607 & 9.193 & 0.000 & 0.469 & 0.731 & Yes $^{* * *}$ \\
\hline 3 & Willingness to pay $\longrightarrow$ Customer satisfaction & 0.509 & 4.174 & 0.000 & 0.249 & 0.732 & Yes $^{* * *}$ \\
\hline 4 & Customer Satisfaction $\longrightarrow$ Customer loyalty & 0.730 & 9.926 & 0.000 & 0.553 & 0.845 & Yes $^{* * *}$ \\
\hline 5 & Wi-Fi $\longrightarrow$ Customer loyalty & 0.197 & 2.720 & 0.007 & 0.067 & 0.355 & Yes $^{* *}$ \\
\hline
\end{tabular}

TABLE 6: $\mathrm{R}^{2}$ y collinearity (VIF values).

\begin{tabular}{|c|c|c|c|c|}
\hline Constructs & $\mathrm{R}^{2}$ & $\mathrm{R}^{2}$ adjusted & Item & VIF \\
\hline Customer satisfaction & 0.450 & 0.440 & Quality & 1.000 \\
\hline \multirow{2}{*}{ Service quality } & \multirow{2}{*}{0.368} & \multirow{2}{*}{0.363} & Products & 1.263 \\
\hline & & & Comfort & 1.263 \\
\hline Wireless communications and Wi-Fi networks & - & - & Connectivity & 1.000 \\
\hline \multirow{2}{*}{ Willingness to pay } & \multirow{2}{*}{-} & \multirow{2}{*}{-} & Prices & 1.461 \\
\hline & & & Wait time & 1.461 \\
\hline Customer loyalty & 0.657 & 0.651 & Recommend & 1.000 \\
\hline
\end{tabular}

each construct is more strongly related to its own measures than to the those of other constructs.

5.2. Second Phase: Structural Model. The evaluation of the structural model implies an analysis of the predictive capacities of the model and the relation between the studied constructs. We evaluated the structural model by evaluating collinearity; the algebraic sign, the magnitude, and the signification of the coefficients of the path coefficients $(\beta)$; the $\mathrm{R}^{2}$ values (explained variance); the size of the effect $f^{2}$; and the test $\mathrm{Q}^{2}$ (validated crossed redundancy) for predictive relevance [87].

For these evaluations, bootstrapping was used, and the results where later compared to the statistics obtained; finally, the signification statistic of the coefficient's path was evaluated.

As can be seen in the results summarized in Table 5, all hypotheses were supported by our data analyses, with p-values being the highest for Hypotheses 2-4 (so that the observed differences were significant at 0.001 level). Hypothesis $1(\beta=0.227 ; t=2.339)$ and Hypothesis 5 on the impact of wireless communications and Wi-Fi on customer loyalty ( $\beta=0.197 ; t=2.720)$ obtained the lowest levels of trust $(99 \%)$. The strongest relation was for the impact of customer satisfaction on customer loyalty $(\beta=0.730 ; \mathrm{t}=9.926)$, followed by that of willingness to pay on service quality $(\beta=0.607$; $=9.193)$.
The weakest relation was between wireless communications and Wi-Fi and customer loyalty $(\beta=0.197 ; \mathrm{t}=2.720)$.

To verify the problem of collinearity, we examined the values of VIF of all the predictor constructions (see Table 6). All VIF values were under the conventional standard of 5; therefore, collinearity between constructs was not a critical problem in the structural model.

Table 6 shows the results obtained from the codetermination coefficient $\mathrm{R}^{2}$. The test performed shows the main dependent construct $\mathrm{R}^{2}$ Customer Loyalty $=65.7 \%$ of the variance. In previous research $[78,81,90]$, the cut-off points were set at $0.75,0.50$, and 0.25 for the same three levels (relevant, moderate, and weak).

As suggested by the results, this model is moderately applicable in the context of the factors that affect loyalty towards fast food restaurants. Customer satisfaction and service quality had substantial $\mathrm{R}^{2}$ values of $0.45 \%$ and $36.8 \%$, respectively. Regarding the size of the $f^{2}$ effect to relate to the structural model, customer loyalty was found to have a big-sized effect in service quality and willingness to pay: the corresponding values were 0.059 and 0.297 , respectively. At the same time, service quality was found to have a big effect in willingness to pay (0.583). Finally, the size of the effect produced by customer loyalty with wireless communications and Wi-Fi networks was small (0.103).

Next, the bandages were used to evaluate the model with the redundancy index with crossed $\left(Q^{2}\right)$ validation for the 
TABLE 7: PLS Predict assessment.

\begin{tabular}{|c|c|c|c|c|c|c|c|c|c|}
\hline \multirow[t]{2}{*}{ Items } & \multicolumn{3}{|c|}{ PLS } & \multicolumn{3}{|c|}{ LM } & \multicolumn{3}{|c|}{ PLS-LM } \\
\hline & RMSE & MAE & $\mathrm{Q}^{2}$ & RMSE & MAE & $\mathbf{Q}^{2}$ & RMSE & MAE & $Q^{2}$ \\
\hline \multicolumn{10}{|c|}{ Complete Sample Model } \\
\hline $\begin{array}{l}\text { Customer Loyalty } \\
\text { (Recommend) }\end{array}$ & 1.528 & 0.948 & 0.485 & 1.49 & 0.971 & 0.51 & 0.038 & -0.023 & -0.025 \\
\hline $\begin{array}{l}\text { Customer Satisfaction } \\
\text { (Quality) }\end{array}$ & 1.751 & 1.097 & 0.396 & 1.74 & 1.121 & 0.404 & 0.011 & -0.024 & -0.008 \\
\hline $\begin{array}{l}\text { Service Quality } \\
\text { (Comfort) }\end{array}$ & 1.163 & 0.832 & 0.075 & 1.164 & 0.845 & 0.075 & -0.001 & -0.013 & 0 \\
\hline $\begin{array}{l}\text { Service Quality } \\
\text { (Products) }\end{array}$ & 1.177 & 0.878 & 0.361 & 1.148 & 0.827 & 0.393 & 0.029 & 0.051 & -0.032 \\
\hline
\end{tabular}

endogenous variables. Chin [86] suggested this measurement to examine predictive relevance of theoretical /structural models. The $\mathrm{Q}^{2}$ values above zero imply that a model has predictive relevance. The results obtained for customer loyalty $\left(Q^{2}=0.440\right)$ confirm that the structural model has a satisfactory predictive relevance. The remaining endogenous constructions confirm this result as well: service quality $\left(Q^{2}=0.226\right)$ and customer satisfaction $\left(Q^{2}=0.409\right)$.

With respect to the approximate adjustment measurements of the model [95], the value obtained from the standardized root mean square residual (SRMR) [96, 97] measures the difference between the matrix of the observed correlations implied by the model. Therefore, the SRMR reflects the average magnitude of such differences: the lower the SRMR, the better the fit. In our case, $S R M R=0.08$, i.e., only slightly below the recommendation of SRMR $<0.08$ [96]. Therefore, our adjustment can properly fit in the exact limit of the composed factor model, constituting hence a compound confirmatory analysis [76].

5.3. Predictive Validity Evaluation. We analyzed the set of items of the endogenous constructs of the model to measure the predictive capacity of the proposed model: customer loyalty (Recommend), customer satisfaction (Quality), service quality (Comfort), and service quality (Products). The objective was to predict each item or dependent variable [98]. In our case, the final dependent variable was customer loyalty. The approach suggested by Shmueli et al. [99] was used in this study. For this, it was evaluated through cross validation with retained samples.

Using the studies of other authors [100, 101], the current PLS prediction algorithm was used in the SmartPLS software [85]. This software gave results like the R Mean Square Error (RMSE) and the Mean Absolute Error (MAE). As can be seen in Table 7, we evaluated the predictive performance of the PLS model for indicators of dependent constructs [100, 101].

The $\mathrm{Q}^{2}$ value in "PLS Predict" indicates that the prediction errors of the PLS model were compared with the simple mean predictions. If the value of $\mathrm{Q}^{2}$ is negative, the prediction error of the PLS-SEM results is greater than the prediction error of simply using the mean values. As a result, the PLSSEM model offered inappropriate predictive performance. As we can see in Table 7, all the values of the last column are very close to 0 and negative in most of the items, which means that we obtained poor prediction results.

The Linear Regression Model (LM) approach is a regression of all exogenous indicators in each endogenous indicator. When this comparison is made, an estimate of where better prediction errors can be obtained is the result. This is shown when the RMSE and MAE value of PLS are lower than the values of the LM model. The results only indicate this predictive capacity (see Table 7) in the case of the service quality (Products) indicator, since it is the only item with negative RMSE and MAE values, which indicated a good predictive power.

The density diagrams of the residues within the sample and outside the sample are given in Figure 3.

As a result of the different analyses, this research did not find sufficient evidence to support the predictive validity (out-of-sample prediction) of our research model in order to predict values for new cases of recommend in Customer Loyalty. Therefore, the model can not predict the intention of recommending additional samples that are different from the data set that was used to test the theoretical research model [102].

5.4. Considerations for Customer Loyalty through Wi-Fi Networks (IPMA). In line with the research that studied the heterogeneity of the data [103], the IPMA-PLS technique was used to find more precise recommendations for customer loyalty through Wi-Fi networks. IPMA is a grid analysis that uses matrices that allows combining the total effects of the "importance" of PLS-SEM estimation with the average value score for "performance" $[103,104]$. The results are presented in an importance-performance graph. For Groß [103], the interpretation of Figure 4 is to demonstrate the recommendation attributes (Customer Loyalty) that are highly valued for performance and importance. The results obtained will be of great interest for Restaurants and Hospitality for those that are developing loyalty techniques in which one of the factors used is the Wi-Fi network.

The results show that most of the factors are in quadrants 1 and 2 (upper left and right in Figure 4). Quadrant 1 shows attributes of recommendation of great importance, but of low performance, which must be improved. In this case, loyalty techniques should be based on Wi-Fi and service quality, which show an average performance. Quadrant 2 


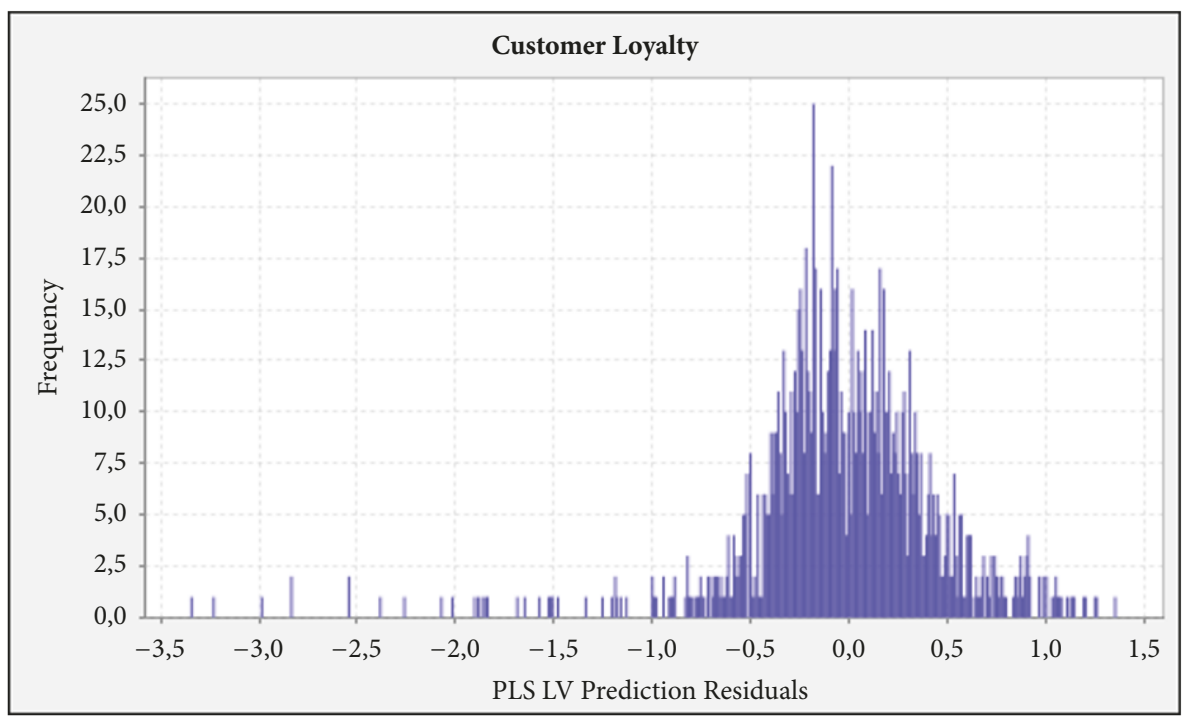

FIGURE 3: Residue density within the sample and outside the sample.

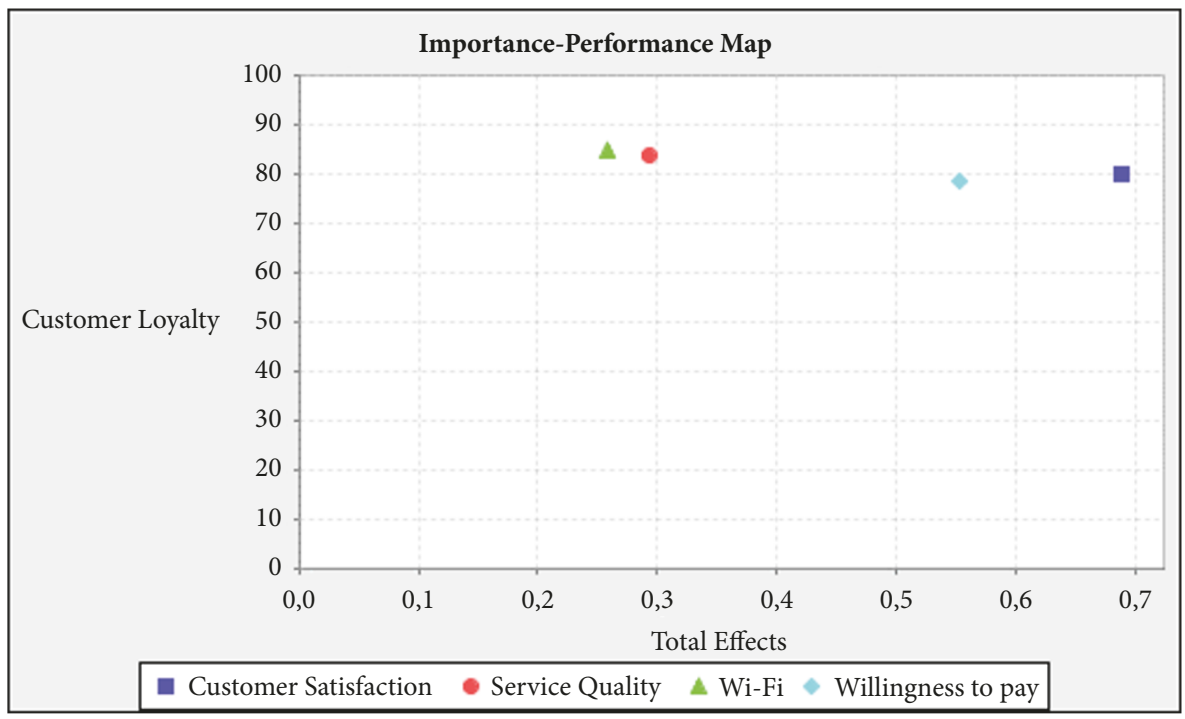

FIGURE 4: Importance-performance maps.

shows recommendation attributes of high importance and performance. These are mainly customer satisfaction and, to a lesser extent, performance, willingness to pay.

The results obtained show two different situations. These consumers and Wi-Fi users rated the importance $>75$ in all the constructs, while the performance varied from 0.25 in $\mathrm{Wi}$ $\mathrm{Fi}, 0.3$ in service quality, 0.55 in willingness to pay, and 0.7 in the case of customer satisfaction.

The results indicate that $\mathrm{Wi}-\mathrm{Fi}$ has the highest valuation, although it is the one that obtains the least performance within the model studied. Therefore, it is in this construct that improvements in performance must be made. Most marketing actions should be taken emphasizing the use of $\mathrm{Wi}-\mathrm{Fi}$ as an element that can contribute to customer loyalty.
5.5. Mediation Effect of Service Quality. The causal effect of the variable $X$ can be divided in an indirect effect over $\mathrm{Y}$ through $\mathrm{M}(\mathrm{a} * \mathrm{~b})$ and a direct effect on $\mathrm{Y}$ (path $c^{\prime}$ ). Confidence intervals (CI) are reported in Table 7 and, if value 0 was obtained, then the mediation was not considered to be statistically significant. If the signification was significant, then we would calculate the total effect of $X$ over $Y=c$, where $c=c^{\prime}+a b$. X turned out to be significant $(\beta=0.607 ; t=9.010)$ at the confidence level of $99 \%$.

The first step was to test the mediating hypothesis (Hypothesis 6) to determine the level of significance of the indirect effects (ai x bi), as c' (willingness to pay $\longrightarrow$ customer satisfaction) yielded significant results. At the same time, two types of partial mediation were found: the complementary one where $\mathrm{a} x \mathrm{~b}, \mathrm{y} \mathrm{c}^{\prime}$ had the same direction (positive in our 


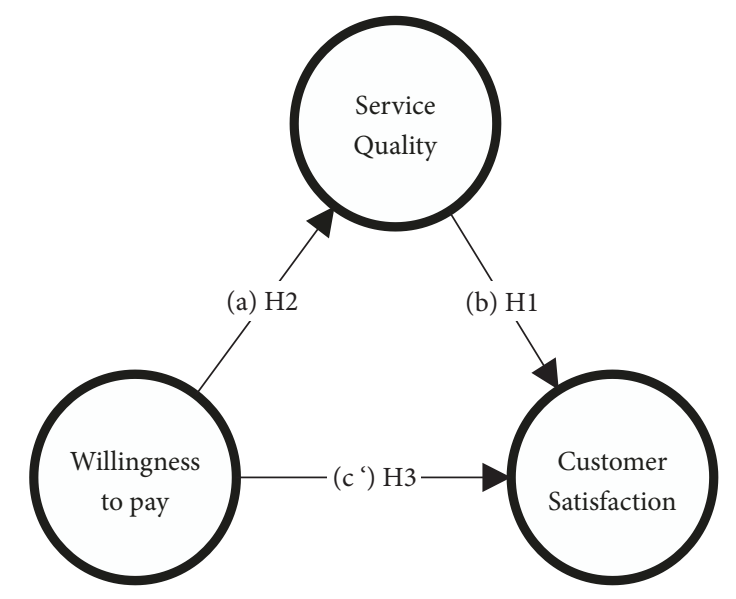

FIgURE 5: Mediation of service quality in the relation WP $\longrightarrow$ CS.

TABLE 8: Mediating effects.

\begin{tabular}{lccc}
\hline & $\begin{array}{c}\text { Path coeff } \\
(\beta)\end{array}$ & $\begin{array}{c}\text { CI (2.5\%) } \\
\text { LOWER }\end{array}$ & $\begin{array}{c}\text { CI (97.5\%) } \\
\text { UPPER }\end{array}$ \\
\hline $\begin{array}{l}\text { a: Willingness to pay } \longrightarrow \\
\begin{array}{l}\text { Service quality } \\
\text { b: Service quality } \longrightarrow\end{array}\end{array}$ & 0.607 & 0.479 & 0.733 \\
$\begin{array}{l}\text { Customer satisfaction } \\
\text { c Willingness to pay } \longrightarrow\end{array}$ & 0.227 & 0.031 & 0.414 \\
$\begin{array}{l}\text { Customer satisfaction } \\
\text { a*b: Indirect effects }\end{array}$ & 0.509 & 0.263 & 0.739 \\
\hline
\end{tabular}

case), and the competitive one, where $\mathrm{ax} b, \mathrm{y} \mathrm{c}^{\prime}$ had different directions (one positive and the other negative, or vice versa; in our case, a x b x c $\longrightarrow$ negative [105].

Table 8 reports the main parameters obtained for the studied submodel in the structural model in which the hypothesis of mediation $\mathrm{H} 6$ refers to the following: The relation of willingness to pay over customer satisfaction is mediated by service quality (see Figure 5).

Therefore, willingness to pay $\longrightarrow$ customer satisfaction $\left(c^{\prime}=0.509^{* *}\right)$ was found to be compatible when it was significant. Consistently, it was still significant in willingness to pay $\longrightarrow$ service quality $\left(\mathrm{a}=0.607^{* * *}\right)$ and service quality $\longrightarrow$ customer satisfaction $\left(\mathrm{b}=0.227^{* *}\right)$.

Consequently, customer satisfaction in the dimension of willingness to pay decreased when quality service was included ( $\mathrm{a} \times \mathrm{b}=0.309$ ). Furthermore, we found significant paths such as a and $b$; therefore, the significant increment manifested in the direct state $\left(c^{\prime}\right)$, since the signification of the regression coefficients ( $a$ and $b$ ), suggests a possible existence of an indirect effect of service quality on the partial relation between both constructs, with service quality as the mediating variable.

However, the key condition to determine the implied effect is to prove the importance of $\mathrm{a} \times \mathrm{b}=$ path of willingness to pay $\longrightarrow$ service quality $\times$ path service quality $\longrightarrow$ customer satisfaction [106]. With this in mind, we obtained values for this indirect effect $(\mathrm{a} \times \mathrm{b}=0.309$; see Table 9$)$ of SmartPLS.
TABLE 9: Moderating effects.

\begin{tabular}{lcccc}
\hline & $\begin{array}{c}\text { Path coeff } \\
(\beta)\end{array}$ & $\begin{array}{c}\text { Statistics t } \\
(\beta / \text { STDEV })\end{array}$ & $p$ & Support \\
\hline $\begin{array}{l}\text { Customer satisfaction } \\
\longrightarrow \text { Customer loyalty }\end{array}$ & 0.683 & 7.097 & 0.000 & Yes $^{* * *}$ \\
$\begin{array}{l}\text { Moderating effects } \\
\longrightarrow \text { Customer loyalty }\end{array}$ & -0.106 & 1.459 & 0.145 & n.s. \\
$\begin{array}{l}\text { Wi-Fi network } \\
\text { services } \longrightarrow\end{array}$ & 0.187 & 2.671 & 0.008 & Yes $^{* *}$ \\
Customer loyalty & & & & \\
\hline
\end{tabular}

This indirect effect was significant, as confidence interval (CI) was not 0 , confirming the mediation effect (Hypothesis 6). All situations were under the condition that both the direct effect $c^{\prime}$ and the indirect effect $\mathrm{ax} b, \mathrm{y} c^{\prime}$ had the same positive direction [105].

According to Hair et al. [72], the decision should not depend on the significance of one of the parameters. Therefore, the criteria should be established, as shown in (1), depending on what part of the total effect of the independent variable over the dependent one is due to mediation (VAF = Variance Accounted For). Our results were as follows: VAF $>$ 80\%: Complete Mediation $20 \% \leq$ VAR $\leq 80 \%$ Partial mediation and $\mathrm{VAF}<20 \%$. Therefore, there was no mediation [72].

$$
\begin{aligned}
& \text { VAF } \\
& =\frac{(\beta \mathrm{WP} \rightarrow \mathrm{SQ} \times \beta \mathrm{SQ} \rightarrow \mathrm{CS})}{((\beta \mathrm{WP} \rightarrow \mathrm{SQ} \times \beta \mathrm{SQ} \longrightarrow \mathrm{CS})+\beta \mathrm{WP} \rightarrow \mathrm{CS})}
\end{aligned}
$$

The result was $\mathrm{VAF}=0.377$; accordingly, we concluded there was a partial mediation with a $37.7 \%$ magnitude [72].

5.6. Moderation Effect of Wireless Communications and Wi-Fi Networks Services. The moderator effects are very important in the study of the PLS Model, just as the one proposed in this study. Generally, a moderator can be defined as a variable that affects the direction and/or the force of the relation between an independent variable or a predictor and a dependent variable or criteria [107].

In our model, one of the main goals was to understand the influence of the construct of free wireless communications and Wi-Fi access on customer loyalty. To this end, we proposed wireless communications and Wi-Fi networks as a moderation variable of the model (see Figure 6). To evaluate it, the product perspective $[108,109]$ was used. This perspective is used only when the independent variable and the moderation variable are factors or measurements for only one indicator, as in our case when the three intervening constructs only had one item [110].

After multiplying each indicator of the exogenic variable per the moderating variable, we proceeded to use the product indicators to create the moderating term (see Table 9).

The obtained results suggest that there was no mediating effect of wireless communications and $\mathrm{Wi}$-Fi networks access over the relation between customer satisfaction $\longrightarrow$ customer loyalty, as $p=0.145$ (see Table 9). Therefore, Hypothesis 7 had 


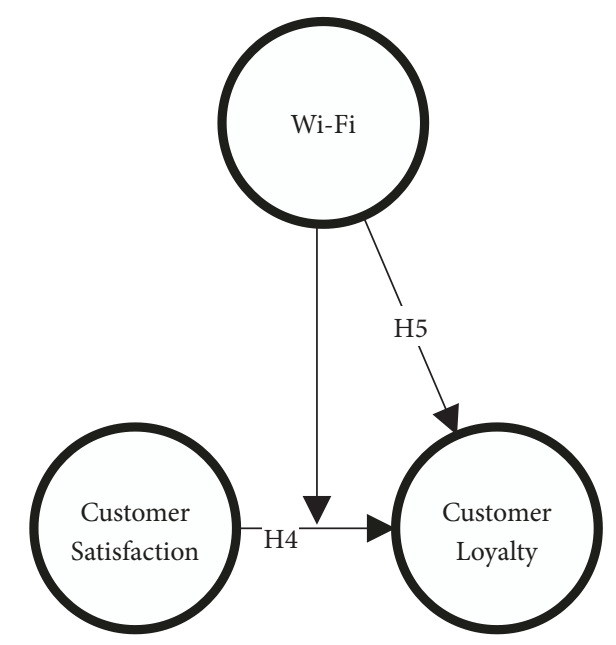

FIGURE 6: Moderation of Wi-Fi access on the relation CS $\longrightarrow$ CL.

to be rejected. Thus, H7 was not supported, and it can be concluded that no moderation effect exists. To determine the force (not signification) of the mediating effects, the $f^{2}$ index was used.

To this end, we compared the model of direct effect with the moderating relation and with the model of moderating terms. The conventions are as follows: $f^{2}>0.02=$ weak moderator effect, $f^{2}>0.15=$ moderate mediating effect and if $f^{2}>0.35=$ strong moderative effect. In our case, the $f^{2}$ index of the moderate effect was 0.047 , which is considered to be a weak effect.

\section{Discussion}

In the present study, we investigated the relation between restaurant client behavior and the factors that influence customer loyalty. In recent years, new technologies in the catering sector have started to be widely used so as to develop tactics to increase customer loyalty and customer satisfaction. In line with the growing importance of wireless communications and Wi-Fi networks in the perception of users to promote returning, our results demonstrate the strong impact that wireless communications and Wi-Fi networks have on repeated use of restaurant services. Furthermore, our findings also suggest that the quality of the service influences customer satisfaction, making clients perceive a higher quality in the delivered service. From the applied perspective, our work suggests the need to further investigate the impact of wireless communications and Wi-Fi networks access on customer loyalty, since the latter promotes repeated use of restaurant services.

Our first hypothesis on the positive impact of the quality of service in restaurants on consumer satisfaction (H1) was supported by the data analysis. This is congruent with Saravanan and Veerabhadraiah's (2003) finding that service quality is directly perceived by consumers and can increase their loss of satisfaction with respect to the products and services.
Similarly, our prediction on the positive influence of willingness to pay on quality of service (Hypothesis 2) was also supported, as consumers correlated the quality of service with what they were willing to pay for. Furthermore, in support of Hypothesis 3, our results also demonstrate that consumers' willingness to pay in a restaurant has a positive influence on their satisfaction due to, among other factors, the customers' decision-making in relation to what they are willing to pay.

Furthermore, our hypothesis that customer satisfaction would positively influence consumer loyalty (Hypothesis 4) was also supported by our results, as satisfaction with the products and services acquired at the point of sale was found to increase loyalty and engagement of consumers inside the restaurant. One of the factors perceived by customers to positively increase the quality of service was wireless communications and Wi-Fi. Similarly, a previous study also demonstrated that consumers valued the speed of the connection $n$ a retail selling point [16].

Nevertheless, according to our results, consumers do not realize that their appreciation of free wireless communications and Wi-Fi causes an increase in their loyalty (Hypothesis 5). While consumers perceive wireless communications and Wi-Fi networks as a complementary service, this additional service might even increase their desire to return to the establishment if the experience was positive [22]. Likewise, it should be emphasized that willingness to pay over customer satisfaction was measured through service quality (H6), which implies that consumers were satisfied after comparing product price, product quality perception, as well as with the quality of the service [24].

The results of the present study are meaningful for managers in catering establishments, as our findings suggest meaningful implementations that can enhance the quality of client service and ultimately improve the general conditions of their retail point of sale [23].

Taken together, our results convincingly demonstrate that technologies such as wireless communications and $\mathrm{Wi}-\mathrm{Fi}$ networks offer great opportunities in terms of understanding customer behavior in retail points of sale, particularly in the catering domain. The environment of the retail points of sale and establishments has become a measuring device for product attractiveness and consumer satisfaction with the offered services. Therefore, wireless communications and $\mathrm{Wi}$ Fi networks should be considered as key identifiers of an appropriate development of a relationship between restaurant clients and the catering establishment; more specifically, free high-quality wireless communications and Wi-Fi networks services generate long-term clientele and promote customer loyalty (Saravanan \& Veerabhadraiah, 2003) [23].

\section{Conclusions}

The results of the present study provide meaningful insights for company managers in the catering sector regarding the ways to improve their client services and, consequently, increase the number of loyal customers. Our findings demonstrate the existence of a correlation between quality and price 
TABLE 10

\begin{tabular}{lcc}
\hline Constructs/Authors & Items & Path \\
\hline $\begin{array}{l}\text { Willingness to pay [29]; } \\
\text { (Kemény, 2015) }\end{array}$ & $\begin{array}{c}\text { It was easy to pay for the products. } \\
\text { The waiting time was reasonable. }\end{array}$ & 0.872 \\
$\begin{array}{l}\text { Service quality } \\
\text { (Francis, 2009) }\end{array}$ & $\begin{array}{c}\text { The restaurant was visually appealing. } \\
\text { The range of the offered products was good. }\end{array}$ \\
$\begin{array}{l}\text { Customer loyalty } \\
\text { (Yang \& Peterson, 2004) }\end{array}$ & $\begin{array}{c}0.895 \\
\text { I would recommend this restaurant to those who seek my advice on } \\
\text { Customer satisfaction } \\
\text { (Anderson \& Srinivasan, 2003) }\end{array}$ \\
\hline $\begin{array}{l}\text { Wireless communication and } \\
\text { Wi-Fi services (Chang et al., } \\
2009)\end{array}$ & The restaurant is willing and ready to respond to customer needs. \\
\hline
\end{tabular}

of wireless communications and Wi-Fi networks, on the one hand, and customer loyalty, on the other hand.

Next, it is interesting to point out the established relation between willingness to pay and the quality of service which is directly related to variables such as price. Similarly, the influence of willingness to pay on customer satisfaction was also confirmed by our findings. In this respect, restaurant managers should take into account that customer predisposition to pay for a product or service, arising from a customer's conviction of having "a good deal", influences customer satisfaction. Taken together, our results demonstrate that customer satisfaction positively influences customer loyalty. This conclusion provides a meaningful insight for restaurant managers: specifically, free wireless communications and $\mathrm{Wi}$ Fi networks services linked to the retail point of sale can increase long-term customer loyalty and, therefore, should be among the priorities to be considered by restaurant managers.

Wi-Fi networks serve as a mean to promote customer loyalty so if marketers find the way to create value for customers they can use the Wi-Fi networks for several purposes that range from strategic content communication with the access pages to branding.

Similarly, our results suggest that the relation between willingness to pay and customer satisfaction is mediated by the effect of service quality. Said differently, clients perceive willingness to pay through the satisfaction they get from a given company or brand, which allows them to directly perceive an optimal service quality. Therefore, customers' willingness to pay determines satisfaction that clients get from the obtained products and services. Moreover, it is important to highlight the mediation effect of wireless communications and Wi-Fi networks in the relation between customer satisfaction and customer loyalty, which makes Wi$\mathrm{Fi}$ and wireless communications key antecedents of clients' satisfaction and purchase intention. In this respect, the model proposed in the present study is particularly useful, as it can serve as a basis for future studies to implement improvements in consumer loyalty in restaurants through wireless communications and Wi-Fi networks or to elaborate relevant strategies to increase satisfaction and quality of service.
In future studies, the analysis developed can be conducted with a larger sample. This could be extended to other restaurants and future studies could focus on comparative analysis in order to find advantages in terms of marketing implications.

The limitations of the present study relate to the sample size and the selection of the restaurant. Our results can be used in the future to inform other theories and models of user loyalty and new technologies like wireless communications and Wi-Fi networks.

\section{Appendix}

\section{Items and Constructs}

The questionnaire items have been adapted from studies specified in Table 10, as well as from Kemény (2015) and Sharma and Stafford (2000). The table includes the questions on which the indicators of each construct are based.

\section{Data Availability}

The data survey used to support the findings of this study is included within the article.

\section{Conflicts of Interest}

The authors declare that there are no conflicts of interest regarding the publication of this paper.

\section{References}

[1] V. Valentinov, "Understanding the rural third sector: Insights from Veblen and Bogdanov," Kybernetes, vol. 41, no. 1-2, pp. 177188, 2012.

[2] R. J.-H. Wang, E. C. Malthouse, and L. Krishnamurthi, "On the Go: How Mobile Shopping Affects Customer Purchase Behavior," Journal of Retailing, vol. 91, no. 2, pp. 217-234, 2015.

[3] D. Cyr, M. Head, and A. Ivanov, "Design aesthetics leading to mloyalty in mobile commerce," Information \& Management, vol. 43, no. 8, pp. 950-963, 2006. 
[4] W. Xiaoliang, K. Xu, and Z. Li, "SmartFix: Indoor Locating Optimization Algorithm for Energy-Constrained Wearable Devices," Wireless Communications and Mobile Computing, vol. 2017, Article ID 8959356, 13 pages, 2017.

[5] L. Wu, "Understanding the Impact of Media Engagement on the Perceived Value and Acceptance of Advertising Within Mobile Social Networks," Journal of Interactive Advertising, vol. 16, no. 1, pp. 59-73, 2016.

[6] J. Yim, S. Ganesan, and B. H. Kang, "Location-Based Mobile Marketing Innovations," Mobile Information Systems, vol. 2017, Article ID 1303919, 3 pages, 2017.

[7] K. Dong, Z. Ling, X. Xia, H. Ye, W. Wu, and M. Yang, "Dealing with Insufficient Location Fingerprints in Wi-Fi Based Indoor Location Fingerprinting," in Wireless Communications and Mobile Computing, 2017.

[8] Y. H. Kim, D. J. Kim, and K. Wachter, "A study of mobile user engagement (MoEN): Engagement motivations, perceived value, satisfaction, and continued engagement intention," Decision Support Systems, vol. 56, no. 1, pp. 361-370, 2013.

[9] J. V. Doorn, K. N. Lemon, V. Mittal et al., "Customer Engagement Behavior: Theoretical Foundations and Research Directions," Journal of Service Research, vol. 13, no. 3, Article ID 1094670510375599, pp. 253-266, 2010.

[10] A. Backlund, "The concept of complexity in organisations and information systems," Kybernetes, vol. 31, no. 1, pp. 30-43, 2002.

[11] P. R. Palos-Sanchez, J. M. Hernandez-Mogollon, and A. M. Campon-Cerro, "The behavioral response to Location Based Services: An examination of the influence of social and environmental benefits, and privacy," Sustainability, vol. 9, no. 11, 2017.

[12] P. C. Verhoef, P. Kannan, and J. J. Inman, "From Multi-Channel Retailing to Omni-Channel Retailing," Journal of Retailing, vol. 91, no. 2, pp. 174-181, 2015.

[13] V. A. Zeithaml, "Consumer Perceptions of Price, Quality, and Value: A Means-End Model and Synthesis of Evidence," Journal of Marketing, vol. 52, no. 3, pp. 2-22, 2018.

[14] P. E. Ramirez-Correa, F. J. Rondan-Cataluña, and J. ArenasGaitán, "Predicting behavioral intention of mobile Internet usage," Telematics and Informatics, vol. 32, no. 4, pp. 834-841, 2015.

[15] S. Husnjak, D. Perakivic, and I. Forenbacher, "Data Traffic Offload from Mobile to Wi-Fi Networks: Behavioural Patterns of Smartphone Users," in Wireless Communications and Mobile Computing, pp. 1-13, 2018.

[16] N. I. Yusop, K. T. Lee, Z. Mat Aji, and M. Kasiran, "Free WiFi as strategic competitive advantage for fast-food outlet in the knowledge era," American Journal of Economics and Business Administration, vol. 3, no. 2, pp. 352-357, 2011.

[17] H. F. Ariffin, M. F. Bibon, and R. P. Abdullah, "Restaurant's Atmospheric Elements: What the Customer Wants," Procedia Social and Behavioral Sciences, vol. 38, pp. 380-387, 2012.

[18] J. R. Saura, P. Palos-Sßnchez, A. Reyes-Menendez, and P. Palos-Sánchez, "Marketing a través de Aplicaciones Móviles de Turismo (M-Tourism). Un estudio exploratorio," International Journal of World of Tourism, vol. 4, no. 8, pp. 45-56, 2017.

[19] J. R. Saura, P. Palos, and F. Debasa, "El problema de la Reputación Online y Motores de Búsqueda: Derecho al Olvido," Cadernos de Dereito Actual, vol. 8, pp. 221-229, 2017.

[20] M. J. Bitner, "Servicescapes: The Impact of Physical Surroundings on Customers and Employees," Journal of Marketing, vol. 56, no. 2, pp. 57-71, 1992.
[21] P. Kotler, "Atmospherics as a marketing tool," Journal of Retailing, vol. 49, pp. 48-64, 1973.

[22] N. D. Line, L. Hanks, and W. G. Kim, "Hedonic adaptation and satiation: Understanding switching behavior in the restaurant industry," International Journal of Hospitality Management, vol. 52, pp. 143-153, 2016.

[23] J.-Y. Park and S. S. Jang, "Revisit and satiation patterns: Are your restaurant customers satiated?” International Journal of Hospitality Management, vol. 38, pp. 20-29, 2014.

[24] T. A. E. F. El-Sherie and M. S. Ghanem, "Free Wi-Fi Service as a Competitive Advantage in Public Cafés," International Journal of Heritage, Tourism, and Hospitality, vol. 8, no. 1, 2016.

[25] S. DCunha, V. Kumar, V. Angadi, and S. Suresh, "Structural equation modelling to predict patient perception of services cape and its relation to customer satisfaction and behavioral intention," Asian Journal of Management Research, vol. 7, no. 4, pp. 293-303, 2017.

[26] R. Naidoo and A. Leonard, "Perceived usefulness, service quality and Customer Loyalty incentives: Effects on electronic service continuance," South African Journal of Business Management, vol. 38, no. 3, pp. 39-48, 2007.

[27] B. Zhang and C. He, "Online customer Customer Loyalty improvement: based on TAM psychological perception and loyal behavior model," Advances in Information Technology and Management, vol. 1, no. 4, pp. 162-165, 2012.

[28] N. Masri, F. I. Anuar, and A. Yulia, "Influence of Wi-Fi service quality towards tourists satisfaction and dissemination of tourism experience. Journal of Tourism," Hospitality Culinary Arts, vol. 9, no. 2, pp. 383-398, 2017.

[29] A. Jain and R. Bala, "Differentiated or integrated: Capacity and service level choice for differentiated products," European Journal of Operational Research, vol. 266, no. 3, pp. 1025-1037, 2018.

[30] R. Ahas, A. Aasa, A. Roose, Ü. Mark, and S. Silm, "Evaluating passive mobile positioning data for tourism surveys: An Estonian case study," Tourism Management, vol. 29, no. 3, pp. 469486, 2008.

[31] B. Struminskaya, K. Weyandt, and M. Bosnjak, "The Effects of Questionnaire Completion Using Mobile Devices on Data Quality. Evidence from a Probability-based General Population Panel," Methods, Data, Analyses, vol. 9, no. 2, pp. 261-292, 2015.

[32] A. Afshar Jahanshahi, M. A. Hajizadeh Gashti, S. Abbas Mirdamadi, K. Nawaser, and S. M. Sadeq Khaksar, "Study the Effects of Customer Service and Product Quality on Customer Satisfaction and Customer Loyalty," 2011.

[33] O. Emir, "A study of the relationship between service atmosphere and customer loyalty with specific reference to structural equation modelling," Economic Research-Ekonomska Istraživanja, vol. 29, no. 1, pp. 706-720, 2015.

[34] J. Jeon, "Examining How Wi-Fi Affects Customers Customer Loyalty at Different Restaurants: An Examination from South Korea," 2015.

[35] J. R. Saura, P. R. Palos-Sanchez, and M. A. Rios Martin, "Attitudes to environmental factors in the tourism sector expressed in online comments: An exploratory study," International Journal of Environmental Research and Public Health, vol. 15, no. 3, article 553, 2018

[36] B. H. Booms and M. J. Bitner, "Marketing Services by Managing the Environment," Cornell Hotel and Restaurant Administration Quarterly, vol. 23, no. 1, pp. 35-40, 1982. 
[37] V. Aubert-Gamet, "Twisting servicescapes: Diversion of the physical environment in a re-appropriation process," International Journal of Service Industry Management, vol. 8, no. 1, pp. 26-41, 1997.

[38] S. Dawson, H. Bloch Peter, and N. M. Ridgway, "Shopping Motives , Emotional States, and Retail Outcomes," Journal of Retail, pp. 408-427, 1990.

[39] J. D. Hutton and L. D. Richardson, "Healthscapes: The role of the facility and physical environment on consumer attitudes, satisfaction, quality assessments, and behaviors," Health Care Management Review, vol. 20, no. 2, pp. 48-61, 1995.

[40] N. Guéguen and C. Petr, "Odors and consumer behavior in a restaurant," International Journal of Hospitality Management, vol. 25, no. 2, pp. 335-339, 2006.

[41] Y. Liu and S. Jang, "The effects of dining atmospheric: An extended Mehrabian-Russell model," International Journal of Hospitality Management, vol. 28, no. 4, pp. 494-503, 2009.

[42] K. Yildirim, A. Akalin-Baskaya, and M. Celebi, "The effects of window proximity, partition height, and gender on perceptions of open-plan offices," Journal of Environmental Psychology, vol. 27, no. 2, pp. 154-165, 2007.

[43] A. C. North and D. J. Hargreaves, "The effects of music on responses to a dining area," Journal of Environmental Psychology, vol. 16, no. 1, pp. 55-64, 1996.

[44] R. J. Donovan and J. R. Rossiter, "Store Atmosphere: An environmental psychology approach," Journal of Retailing, vol. 58, pp. 34-57, 1982.

[45] R. L. Oliver, "Whence customer Customer Loyalty?" Journal of Marketing, pp. 33-44, 1999.

[46] H.-H. Lin and Y.-S. Wang, "An examination of the determinants of customer loyalty in mobile commerce contexts," Information and Management, vol. 43, no. 3, pp. 271-282, 2006.

[47] P. R. Palos-Sanchez, J. R. Saura, and F. Debasa, “The Influence of Social Networks on the Development of Recruitment Actions that Favor User Interface Design and Conversions in Mobile Applications Powered by Linked Data," Mobile Information Systems, vol. 2018, Article ID 5047017, 11 pages, 2018.

[48] C. Breidert, M. Hahsler, and T. Reutterer, "A Review of Methods for Measuring Willingness-to-Pay," InnovativeMarketing, vol. 2, no. 4, pp. 8-32, 2006.

[49] V. A. Zeithaml, L. L. Berry, and A. Parasuraman, "The behavioral consequences of service quality," Journal of Marketing, vol. 60, no. 2, pp. 31-46, 1996.

[50] P. A. Dabholkar, C. D. Shepherd, and D. I. Thorpe, "A comprehensive framework for service quality: An investigation of critical conceptual and measurement issues through a longitudinal study," Journal of Retailing, vol. 76, no. 2, pp. 139-173, 2000.

[51] P. Bharati and D. Berg, "Service quality from the other side: Information systems management at Duquesne Light," International Journal of Information Management, vol. 25, no. 4, pp. 367-380, 2005.

[52] A. H. Kemp, "Getting what you paid for: Quality of service and wireless connection to the internet," International Journal of Information Management, vol. 25, no. 2, pp. 107-115, 2005.

[53] D. K. Yoo and J. A. Park, "Perceived service quality: Analyzing relationships among employees, customers, and financial performance," International Journal of Quality \& Reliability Management, vol. 24, no. 9, pp. 908-926, 2007.

[54] R. L. Oliver, "Measurement and evaluation of satisfaction processes in retail settings," Journal of Retailing, vol. 57, no. 3 , pp. $25-48,1981$.
[55] E. Sivadas and J. L. Baker-Prewitt, "An examination of the relationship between service quality, customer satisfaction, and store loyalty," International Journal of Retail \& Distribution Management, vol. 28, no. 2, pp. 73-82, 2000.

[56] A. Parasuraman, V. A. Zeithaml, and L. L. Berry, "A Conceptual Model of Service Quality and Its Implications for Future Research," Journal of Marketing, vol. 49, no. 4, pp. 41-50, 2018.

[57] A. Parasuraman, V. A. Zeithaml, and L. L. Berry, "SERVQUAL: multiple-item scale for measuring customer perceptions of service quality," Journal of Retailing, vol. 64, no. 1, pp. 12-40, 1988.

[58] P. A. Dabholkar and J. W. Overby, "Linking process and outcome to service quality and customer satisfaction evaluations: An investigation of real estate agent service," International Journal of Service Industry Management, vol. 16, no. 1, pp. 1027, 2005.

[59] R. Johnston, “The Determinants of Service Quality: Satisfiers and Dissatisfiers," International Journal of Service Industry Management, vol. 6, no. 5, pp. 53-71, 1995, (Journal Service Industry Management, vol. 16, no. 1, pp. 10-27).

[60] J. J. Cronin Jr., M. K. Brady, and G. T. M. Hult, "Assessing the effects of quality, value, and customer satisfaction on consumer behavioral intentions in service environments," Journal of Retailing, vol. 76, no. 2, pp. 193-218, 2000.

[61] J. J. Cronin Jr. and S. A. Taylor, "Measuring service quality: a reexamination and extension," Journal of Marketing, vol. 56, no. 3, pp. 55-68, 1992.

[62] S. Robinson, "Measuring service quality: Current thinking and future requirements," Marketing Intelligence \& Planning, vol. 17, no. 1, pp. 21-32, 1999.

[63] P. A. Dabholkar, "Consumer evaluations of new technologybased self-service options: An investigation of alternative models of service quality," International Journal of Research in Marketing, vol. 13, no. 1, pp. 29-51, 1996.

[64] E. A. Wall and L. L. Berry, "The combined effects of the physical environment and employee behavior on customer perception of restaurant service quality," Cornell Hotel and Restaurant Administration Quarterly, vol. 48, no. 1, pp. 59-69, 2007.

[65] R. Ulrich, C. Zimring, Q. Xiaobo, J. Anjali, and R. Choudhary, "he role of the physical environment in the hospital of the 21st century: A once-in-a-lifetime opportunity," Report to the center for health design for the designing the 21st century hospital project, 2004.

[66] A. Kugonza, M. Buyinza, and P. Byakagaba, "Linking local communities livelihoods and forest conservation in Masindi district, North Western Uganda," Research Journal of Applied Sciences, vol. 4, no. 1, pp. 10-16, 2009.

[67] E. Kursunluoglu, "Shopping centre customer service: Creating customer satisfaction and loyalty," Marketing Intelligence \& Planning, vol. 32, no. 4, pp. 528-548, 2014.

[68] K. Rice, "Airlines work to improve speed and availability of inflight Wi-Fi," Travel Weekly, vol. 72, no. 10, 2013.

[69] I. Hwang and Y. J. Jang, "Process Mining to Discover Shoppers Pathways at a Fashion Retail Store Using a Wi-Fi-Base Indoor Positioning System," IEEE Transactions on Automation Science and Engineering, vol. 14, no. 4, pp. 1786-1792, 2017.

[70] M. Contigiani, R. Pollini, M. Sturari, A. Mancini, and E. Frontoni, "IoT Architecture for the Processing of Data Collected by a Central Vacuum Cleaner," in Proceedings of the 13th ASME/IEEE International Conference on Mechatronic and Embedded Systems and Applications, vol. 9, 2017. 
[71] F. Al-Turjman, "Impact of user's habits on smartphones' sensors: An overview," in Proceedings of the 2016 HONET-ICT, pp. 70-74, Nicosia, Cyprus, October 2016.

[72] J. F. J. Hair, G. T. M. Hult, C. Ringle, and M. Sarstedt, A primer on partial least squares structural equation modeling (PLS-SEM), SAGE, Thousand Oaks, Calif, USA, 2014.

[73] V. Stan and G. Saporta, "Conjoint Use of Variables Clustering and PLS Structural Equations Modeling," in Handbook of Partial Least Squares, pp. 235-246, 2009.

[74] Z. Awang, A. Afthanorhan, and M. Mamat, "The Likert scale analysis using parametric based Structural Equation Modeling (SEM)," Computational Methods in Social Sciences (CMSS), vol. 4, no. 1, pp. 13-21, 2016.

[75] M. Sarstedt, J. F. Hair, C. M. Ringle, K. O. Thiele, and S. P. Gudergan, "Estimation issues with PLS and CBSEM: Where the bias lies!," Journal of Business Research, vol. 69, no. 10, pp. 39984010, 2016.

[76] J. Henseler, G. Hubona, and P. A. Ray, "Using PLS path modeling in new technology research: updated guidelines," Industrial Management \& Data Systems, vol. 116, no. 1, pp. 2-20, 2016.

[77] W. Reinartz, M. Haenlein, and J. Henseler, "An empirical comparison of the efficacy of covariance-based and variancebased SEM," International Journal of Research in Marketing, vol. 26, no. 4, pp. 332-344, 2009.

[78] J. F. Hair, C. M. Ringle, and M. Sarstedt, "PLS-SEM: indeed a silver bullet," Journal of Marketing Theory and Practice, vol. 19, no. 2, pp. 139-151, 2011.

[79] C. Fornell and J. Cha, "Partial Least Squares. En Advanced Methods of Marketing," 1994.

[80] W. W. Chin and P. R. Newsted, "Structural equation modeling analysis with small samples using partial least squares," Statistical strategies for small sample research, vol. 1, no. 1, pp. 307-341, 1999.

[81] J. F. Hair, C. M. Ringle, and M. Sarstedt, "Partial Least Squares Structural Equation Modeling: Rigorous Applications, Better Results and Higher Acceptance," Long Range Planning, vol. 46, no. 1-2, pp. 1-12, 2013.

[82] J. Cohen, “A power primer," Psychological Bulletin, vol. 112, no. 1, pp. 155-159, 1992.

[83] F. Faul, E. Erdfelder, A. Buchner, and A.-G. Lang, "Statistical power analyses using $G^{\star}$ Power 3.1: tests for correlation and regression analyses," Behavior Research Methods, vol. 41, no. 4, pp. 1149-1160, 2009.

[84] J. Losco, Statistical power analysis for the behavioral sciences, vol. 17, Lawrence Erlbaum Associates, Hilsdale, NJ, USA, 2nd edition, 1998.

[85] C. M. Ringle, S. Wende, and J. M. Becker, "SmartPLS 3," Boenningstedt: SmartPLS GmbH, 2015, http://www.smartpls.com.

[86] W. Chin, "How to write up and report PLS analyses," in Handbook of Partial Least Squares: concepts, methods and applications in marketing and related Fields, V. E. Vinzi, W. W. Chin, J. Henseler, and Y. H. Wang, Eds., pp. 655-690, 2010.

[87] J. L. Roldán and M. J. Sánchez-Franco, "Variance-based structural equation modeling: Guidelines for using partial least squares in information systems research," Research Methodologies, Innovations and Philosophies in Software Systems Engineering and Information Systems, pp. 193-221, 2012.

[88] E. G. Carmines and R. Zeller, Reliability and Validity Assessment, Sage Publications, Newbury Park, Calif, USA, 1979.

[89] K. A. Bollen, Structural Equations with Latent Variables, John Wiley \& Sons, New York, NY, USA, 1989.
[90] J. Henseler, C. M. Ringle, and R. R. Sinkovics, "The use of partial least squares path modeling in international marketing," Advances in International Marketing, vol. 20, no. 1, pp. 277-319, 2009.

[91] D. Barclay, C. Higgins, and R. Thompson, "The Partial Least Squares (PLS) A roach to Causal Modelling: Personal Computer Adoption and Use as an Illustration, Technology Studies," in Special Issue on Research Methodology, pp. 285-309, 1995.

[92] M. Sarstedt, C. M. Ringle, D. Smith, R. Reams, and J. F. Hair, "Partial least squares structural equation modeling (PLS-SEM): A useful tool for family business researchers," Journal of Family Business Strategy, vol. 5, no. 1, pp. 105-115, 2014.

[93] T. K. Dijkstra and J. Henseler, "Consistent partial least squares path modeling," MIS Quarterly: Management Information Systems, vol. 39, no. 2, pp. 297-316, 2015.

[94] C. Fornell and D. F. Larcker, "Evaluating structural equation models with unobservable variables and measurement error," Journal of Marketing Research, vol. 18, no. 1, pp. 39-50, 1981.

[95] J. Henseler, G. Hubona, and P. A. Ray, "Partial least squares path modeling: Updated guidelines," in Partial Least Squares Path Modeling, pp. 19-39, Springer, Cham, Switzerland, 2017.

[96] L. T. Hu and P. M. Bentler, "Fit indices in covariance structure modeling: sensitivity to under-parameterized model misspecification," Psychological Methods, vol. 3, no. 4, pp. 424-453, 1998.

[97] L. T. Hu and P. M. Bentler, "Cutoff criteria for fit indexes in covariance structure analysis: Conventional criteria versus new alternatives," Structural Equation Modeling: A Multidisciplinary Journal, vol. 6, no. 1, pp. 1-55, 1999.

[98] D. Straub, M. C. Boudreau, and D. Gefen, "Validation Guidelines for IS Positivist Research," Communications of the Association for Information Systems, vol. 13, pp. 380-427, 2004.

[99] G. Shmueli and O. R. Koppius, "Predictive analytics in information systems research," MIS Quarterly: Management Information Systems, vol. 35, no. 3, pp. 553-572, 2011.

[100] M. Sarstedt, C. M. Ringle, G. Schmueli, J. H. Cheah, and H. Ting, "Predictive Model Assessment in PLS-SEM: Guidelines for Using PLSpredict," Working Paper, 2018.

[101] C. M. Felipe, J. L. Roldán, and A. L. Leal-Rodríguez, "Impact of organizational culture values on organizational agility," Sustainability, vol. 9, no. 12, 2017.

[102] A. G. Woodside, "Moving beyond multiple regression analysis to algorithms: Calling for adoption of a paradigm shift from symmetric to asymmetric thinking in data analysis and crafting theory," Journal of Business Research, vol. 66, no. 4, pp. 463-472, 2013.

[103] M. Groß, "Heterogeneity in consumers' mobile shopping acceptance: A finite mixture partial least squares modelling approach for exploring and characterising different shopper segments," Journal of Retailing and Consumer Services, vol. 40, pp. 8-18, 2018.

[104] E. E. Rigdon, C. M. Ringle, M. Sarstedt, and S. P. Gudergan, "Assessing heterogeneity in customer satisfaction studies," Advances in International Marketing, vol. 22, pp. 169-194, 2011.

[105] J. L. Roldan and G. Cepeda, PLS-SEM, CFP, Universidad de Sevilla, 4th edition, 2017.

[106] F. Hernández-Perlines, J. Moreno-García, and B. Yañez-Araque, "The mediating role of competitive strategy in international entrepreneurial orientation," Journal of Business Research, 2016.

[107] R. M. Baron and D. A. Kenny, "The moderator-mediator variable distinction in social psychological research: conceptual, strategic, and statistical considerations," Journal of Personality and Social Psychology, vol. 51, no. 6, pp. 1173-1182, 1986. 
[108] D. A. Kenny and C. M. Judd, "Estimating the nonlinear and interactive effects of latent variables," Psychological Bulletin, vol. 96, no. 1, pp. 201-210, 1984.

[109] W. W. Chin, B. L. Marcelin, and P. R. Newsted, "A partial least squares latent variable modeling approach for measuring interaction effects: results from a Monte Carlo simulation study and an electronic-mail emotion/adoption study," Information Systems Research, vol. 14, no. 2, pp. 189-217, 2003.

[110] G. Fassott, J. Henseler, and P. S. Coelho, “Testing moderating effects in PLS path models with composite variables," Industrial Management \& Data Systems, vol. 116, no. 9, pp. 1887-1900, 2016. 


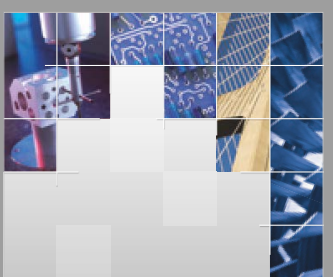

\section{Enfincering}
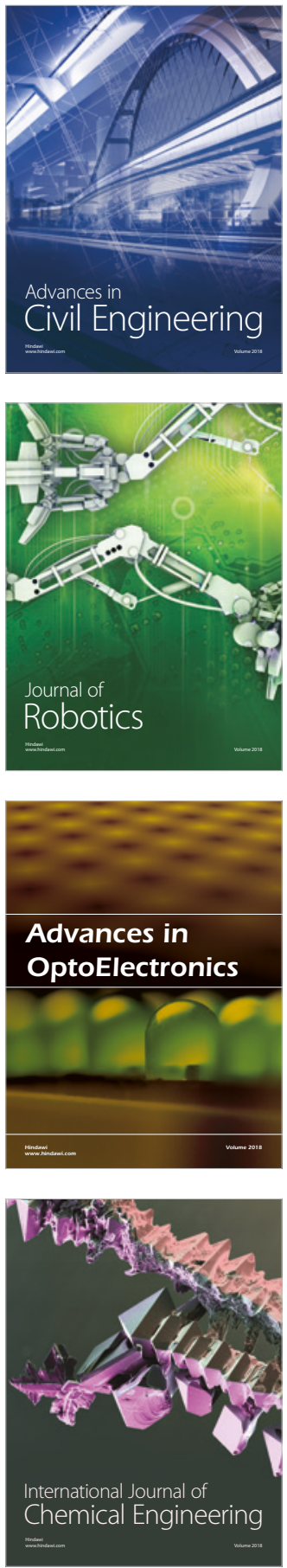

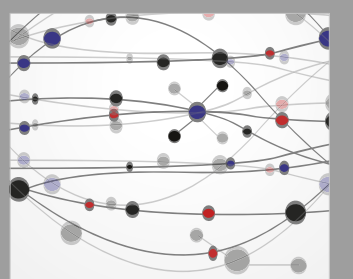

\section{Rotating \\ Machinery}

The Scientific World Journal

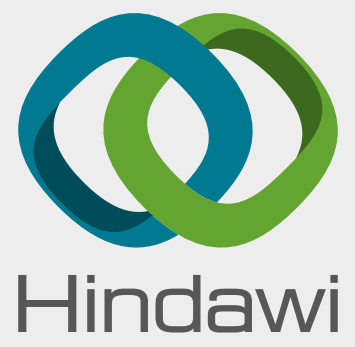

Submit your manuscripts at

www.hindawi.com
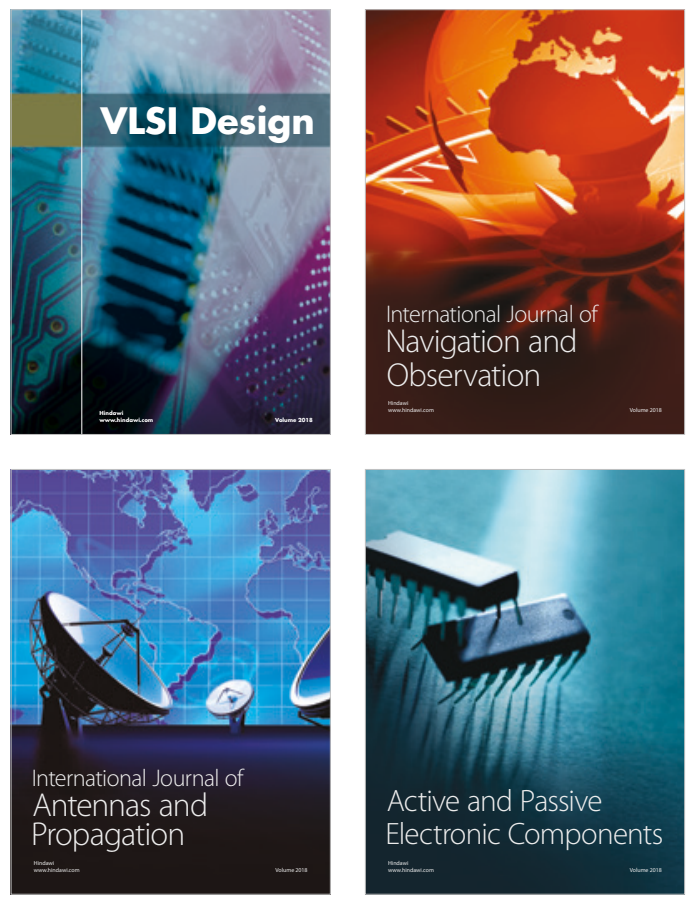
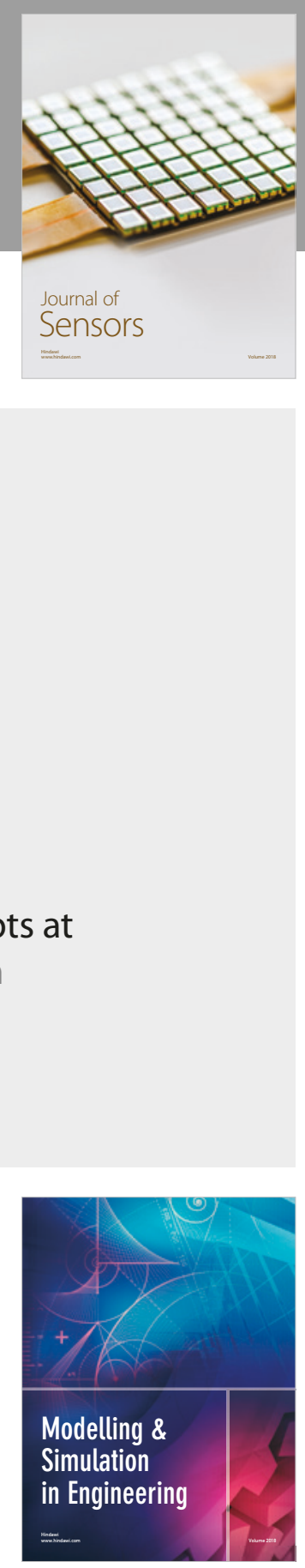

\section{Advances \\ Multimedia}
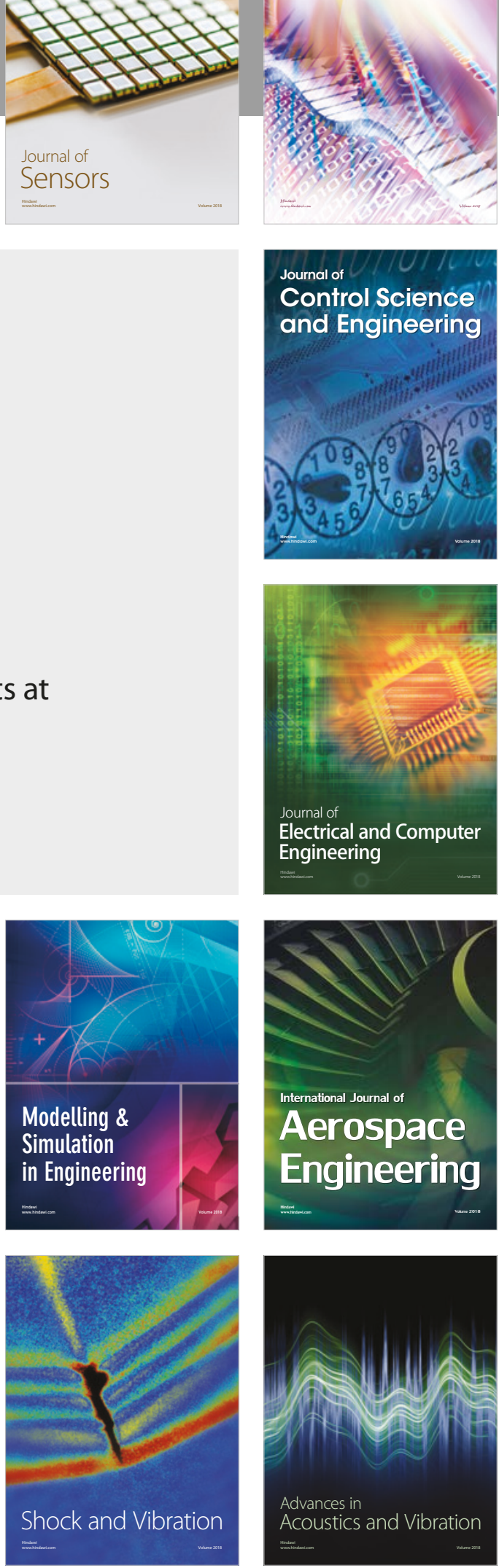